\title{
A Comparative Analysis of Causes of Tom’s and Eliza’s Different Fates in Uncle Tom's Cabin
}

\author{
LIU Xi, WU Yi \\ Changchun University, Changchun, China
}

\begin{abstract}
Since African-Americans were transported to America, more than three hundred years have passed. During the tragic and bitter period of time, African-Americans never stopped their efforts to achieve their freedom. Through the description of two kinds of heroines, Uncle Tom and Eliza, Harriet Beecher Stowe tells us: Tom, who was resigned to bad conditions, obedient to the slave-owner, was doomed to death while Eliza who dared to revolt slavery gained a new life and freedom. To some extent, Uncle Tom's Cabin played an active function to advance social development, especially in the movement of abolitionist and the American Civil War. The present paper focuses on the analysis of the causes of the different fates belonging to Tom and Eliza respectively from the perspectives of the external cause and internal cause and their own characters.
\end{abstract}

Keywords: cause, slavery, character, fate

\section{Introduction}

Uncle Tom's Cabin is an anti-slavery novel which makes people know the tragic history of American slaves in 19th century and reflects the American slaves' unfortunate fates. The writer was Harriet Beecher Stowe, an American abolitionist and author. Coming from a family with good Christian tradition, she was deeply influenced by Christianity and became a pious Christian. She stood up for the belief that slavery should be abolished. Her Uncle Tom's Cabin inspired a generation of abolitionists and set the stage for civil war. Uncle Tom's Cabin depicted life for African-Americans under slavery, and became influential in the United States and United Kingdom and made the political issues of the 1850s regarding slavery tangible to millions, energizing anti-slavery forces in the American North, while provoking widespread anger in the South. Uncle Tom, the hero of this novel, was honest and loyal. Due to his master's debt, he had been sold to different slaveholders for twice. At last he was killed by his last master Legree. Another character of this novel was Eliza who lived in the same plantation with Uncle Tom. When she knew that her son would be sold, she decided to pay any price to gain freedom. She finally went to a free nation-Canada where she found the final happiness. Uncle Tom's Cabin described the evils of the slavery and dramatized the sorrows of the slaves and inhumanity of the institution so vividly that it did more to arouse. The conditions of slaves in 19th century were terrible, including housing, food, and clothing. The black thought that they were a member of human beings with different skin color and 
traditional culture, they had the rights to be free, so they determined to fight against the cruel slavery. The paper aims to analyze the main causes of the different fates belonging to Tom and Eliza from the perspectives of the external cause—-slavery and internal cause — their own characters.

\section{Tom's and Eliza's Different Fates}

In the novel, the two main characters Tom and Eliza had quite different fates. Thus, there was sharp contrast between Tom's misery and Eliza's happiness. Mr. Shelby, who was the first master of Uncle Tom, evaluated that Uncle Tom was steady, honest, and true and square in everything. Mr. Shelby was a kind and gentle master who treated his slaves with kindness and humanity. He gave his slave food and clothes to live a better life, and allowed them to get married with other slaves in his plantation. But because of the debt, Mr. Shelby had to sell Tom and Eliza's little son. Uncle Tom did not know that he would be sold and he still lived in peaceful life on Mr. Shelby's plantation. He managed Mr. Shelby's whole farm including money, horses, and houses. Actually, Tom had the opportunity to run away, but he came back on time and he said, "Ah, master trusted me, and I couldn't” (Stowe, 1999, p. 63). Uncle Tom's life on the plantation was very happy; he not only got his master's trust, but also owned a house and a family. He could not betray his master, even though he had to leave his families and peaceful life in this plantation, even though he did not know what would happen to him in the future. He wanted to show his thanks and loyalty to his master. At the same time he knew that if he ran away, some other slave would be sold instead. He loved his friends so much that he had to stand his own fate.

When Uncle Tom heard the news that he would be free, he raised his hands to heaven "Bless the Lord" (Stowe, 1999. p. 61). Uncle Tom was expecting free and happy life. He thought his tragic life would be ended, God had heard his pious pray and helped him get freedom, but it was the beginning of unfortunate life. As usual St. Clare went to café to look over an evening paper, an affray arose between two gentlemen, he made an effort to separate them and he received a fatal stab. St. Clare's death made Uncle Tom feel hopeless, because he knew that his dream of being free would not come true and he would be sold again. As Uncle Tom predicted, Due to St. Claire's death, the plantation broke down, the slaves on this plantation would be sold in slave warehouse, and at last he was sold to Legree who owned a plantation in the Red river, he could not make sure what would happen on that plantation, so Uncle Tom asked someone on the plantation to write a letter to his home and hoped his family to get enough money to save him.

Eliza was a young quadroon woman, apparently about 25 years old, who also lived in Mr. Shelby's plantation when she was really young till she grew up. Mrs. Shelby was a kind master and she treated her as her own daughter. After she reached maturity, she became beautiful and clever. Mrs. Shelby admitted her to marry a mulatto man call Harris who was also a slave on a neighboring estate. Eliza lived a happy life in the plantation and there was nothing to interrupt her happiness except the loss of two children. Someday, Mr. Shelby told her that the plantation would break down if he did not sell Eliza's son and Uncle Tom. The slave trader would give the highest price for them. Mrs. Shelby was silent, which meant that she had agreed that though she did not say she agreed. Eliza trembled, Harry was all her life, she never permitted anyone to grab her son and she finally decided to flee with her son. She wrote a letter to express her thanks for being cared such a long time and goodwill to Mrs. Shelby. Eliza felt guilty to betray her master but the most important thing now for her was to save her son. She would like to do anything for running away. Eliza packed some clothes and favorite toy for her 
son then awoke Harry. She dressed up him and told him be silent. Little Harry did not know what happened, but in his little heart he realized that there must be something unusual going on. Eliza took her son to Uncle Tom's cabin and told him the news that they have been sold to a slave trader and asked him to run away with them. But Uncle Tom refused them. Eliza decided to run away and she left the plantation she has been living for the past years, never came back.

Uncle Tom was loyal and honest. Because of his master's debt, he had been sold to other slaveholders. Due to his obedience, he had to accept his miserable destiny as a black slave. Another character of this novel was Eliza who lived in the same plantation with Uncle Tom. When she knew that her son would be sold, she decided to pay any price to gain freedom. She was full of encouragement to fight against the slavery and ran away to a free life finally.

\section{External Causes for Their Different Fates-Slavery}

Since African-Americans were transported to the America, more than three hundred years have passed. "During that tragic and bitter period of time, African-Americans never stopped their efforts to achieve their freedom" (Payne, 1996, p. 46). In the Civil War, the famous black leader Dr. Martin Luther King delivered a speech, I have a dream, appealing that the blacks should have the equal rights with the whites. In 1957, he founded the Southern Christian Leadership Conference and moved back to his hometown Georgia. This was the beginning of the Civil Rights Movement. In the following years, he continued to organize non-violent protests against unequal treatment of African-American people. His philosophy remained peaceful, and he constantly reminded his followers that their fight would be victorious if they did not resort to bloodshed. Under the black's struggle, they got the basic rights and freedom. Uncle Tom's Cabin had been finished in this social background; it was published serially in a newspaper in 1857 and in book form the year after. It was widely read in the United States and abroad and moved many to join the cause of abolition.

In 19th century, "as the description in Uncle Tom's Cabin, most of American blacks lived in the south" (Ammons, 2000, p. 37). Some of them lived on the plantation without human rights, freedom, and consideration. The slaves were first brought to America in the 17th century met the needs of laborers. After the Revolution, the Northern slaveholders began to get rid of their slaves because slave labor was not profitable. In the South, things were different. Slaves were working on the large cotton plantations and making huge profits for their white masters but they were treated with cruelty by the masters. The slaves lived in small cabins near their master's big house. They were cruelly treated and the punishments on them were rather severe. They were bought and sold like animals. They did not have basic human rights, they were considered not to need houses and clothes even food. In slaveholders' views, they did not have their own history and culture; they did not have emotions so slaveholders never paid attention to their feelings. Under this condition, the slaves began to struggle for their freedom. In the novel Uncle Tom's Cabin, Eliza was a member of anti-slavery group. She could not accept the separation from her son. Eliza decided to flee from Mr. Shelby's plantation although Mr. And Mrs. Shelby treated her kindly. For happiness of her son, she had to run away with her son to the free country-Canada. She paid any price to fight for the freedom. Though she met a lot of danger on the way to Canada, she did not give up, at last she gained freedom and happiness. Though Uncle Tom knew that he would be sold, he still stayed on the plantation. Under the background of the society, slaves were just their masters' property, they could be sold at 
random and slaves must be obedient to their masters. Uncle Tom thought that he was just a private belonging of his master; it was not weird to be sold and be killed. It was the rules of this society. Uncle Tom was also expecting freedom and happy life with his family, but he was a black man, his role in the society was only goods or labor tools, so one factor of Uncle Tom's tragic fate was the social background.

\section{Internal Causes of Their Different Fates-Their Different Characters}

Uncle Tom was faithful, forgiving, and obedient. He was full of love for his companions. His two most prevalent qualities were his inherent goodness and piety. Uncle Tom was a pious Christian and resembles Jesus in many aspects. He consistently forgave the wrongs committed against him and turned to God in time of crisis. In Shelby's house, Uncle Tom was a sort of patriarch in religious matters in the neighborhood. Having, naturally, an organization in which the morale was strongly predominant, together with a greater breadth and cultivation of mind than his companions, he was looked up, as a sort of minister among them; and the simple, hearty, and sincere style of his exhortations might have edified even better educated persons. But it was in prayer that he especially excelled. In the language of a pious old Negro, he "prayed right up” (Stowe, 1999, p. 91). Mr. Shelby asked Uncle Tom to manage his whole plantation due to his trust to Uncle Tom. St. Clare who gave Tom a bill without looking at it trusted Uncle Tom so much. While he was at Legree's home, he met a pitiful, wretched old slave Prue, whose only child starved to death because she had to devote all her time to tend her mistress and lost her milk, yet her mistress refused to buy milk for her baby. Uncle Tom offered to carry her basket for her and sent the Gospel to her. He was always giving other the belief of life. He said to her, “O, ye poor critter! Hadn’t nobody never telled ye how the Lord Jesus loved ye, and died for ye?” (Stowe, 1999, p. 103). Tom's prayer was answered and his kindheartedness moved others. Although Tom was beaten almost to death, he determined to say nothing. When thundered Legree struck him furiously, Tom answered, “I know, Mas’t, but I can’t tell anything. I can die!” (Stowe, 1999, p. 112). However, Legree couldn't understand him. Facing his third cruel master Simon Legree’s threatening and flogging, he did not choose to complain of Legree's brutality, on the contrary, Uncle Tom forgave him and in his deathbed he hoped his young master on Mr. Shelby's plantation not to hate Legree. Due to his submission, he was end in the death at last. In fact, Uncle Tom was a man with good qualities and immaculate character. He was a stereotype with typical African features and disposition of that race, yet Uncle Tom had the passive character in his life. His non-resistant principle was not accepted by the white readers, but his upright quality was not separated from his firm belief and personal strength. In a word, Uncle Tom was the representative of a kind of person rather than a single man. Whatever happened, he was stick to his belief in Christianity and tried to help others to change by persuasion.

Eliza was brave and adamant. Eliza ran away from Mr. Shelby's plantation with her son on her own. On the fugitive way to Canada, she did not fear the slaveholder's accomplice and never wanted to give up whatever troubles she met. She was very brave when she went through the Ohio River; she jumped into the ice flake and leaped from one to another, though her leg was shot, she still persisted to go across the river. She dared to fight against the slavery, which had proved that she was very brave. For other slaves, they even did not want to try to fight against the slavery, because they knew that the end against the slavery was to be killed. Eliza was also adamant; she did not pay attention to the cold water and the great pain of being shot. Due to her character, she finally got the freedom and happiness. In fact, characters of black people were affectionate, magnanimous and 
forgiving, so the blacks should share the same rights with the whites. At that time, Uncle Tom's character partially determined his tragic fate. His faithfulness, forgiveness, and affection could not change his unfortunate fate and abolish the slavery that had rooted deeply in the society. Eliza realized that only ran away to a freedom place can she and her son live together. She tried to struggle with her fate and she was enough courageous to struggle against the slavery, her struggling changed her slave fate, and she had the freedom, the happy family and jobs like the whites. The most important was that she had become her own master.

\section{Conclusion}

In Uncle Tom's Cabin, the external reason for Tom's death was the slavery, which brought the endless heartbreak and horrors to the slaves, the anguish and despair were riving thousands of hearts, shattering thousands of families, and driving a helpless and sensitive race to frenzy and despair. Eliza was also one sufferer of the slavery, but she was firm and dared to resist against the unequal and inhumane slavery, she got the freedom at the end of this novel. As for their different character, it was the internal cause for their different fates. Tom was the man who can arouse the sympathy from the white. He was a stereotype with typical African features and disposition of that race, yet Tom had the passive character in his life. His non-resistant principle was not accepted by the white readers, but his upright quality was not separated from his firm belief and personal strength. In a word, Tom was the representative of a kind of person rather than a single man. Whatever happened, he stick to his belief in Christianity and tried to help others to change by persuasion. Mrs. Stowe portrayed such a character as Tom because she herself believed in Christianity and was greatly influenced by Christianity and believed in the kindness in human beings.

\section{References}

Ammons, E. (2000). Approach to teaching Stowe's Uncle Tom's Cabin. US: Modern Language Assn of Amer.

Stowe, H. B. (1999). Uncle Tom's cabin. Beijing: World Atlas Publishing Corporation.

HU, Y. T. (1995). Course in America literature. Tianjin: Nan Kai University Press.

John, F. (1995). Cultural studies and cultural value. London: Clarendon Press.

Payne, M. (1996). A dictionary of cultural and critical theory. Oxford: Blackwell Publishers Ltd.

Selden, R., \& Widdowson, P. (2004). A reader's guide to contemporary literary theory. Beijing: Foreign Languages Press.

Bennett, T. (2005). New keywords: A revised vocabulary of culture and society. Oxford: Blackwell Publishing Ltd.

YU, W. X. (2002). Cultural study: An introduction. Beijing: People Press.

ZHANG, K. W. (1988). Survey of Britain and America. Beijing: Science and Technology Press.

ZHANG, S. Y. (2005). History of western literature in 20th century. Beijing: Peking University Press. 